\title{
O PAPEL DA DEFINIÇÃO DE TERMOS TÉCNICO-CIENTÍFICOS*
}

Maria José Bocorny FINATTO

Universidade Federal do Rio Grande do Sul

\section{RESUMO}

Este artigo enfoca as condições de apreensão da natureza e o funcionamento da definição terminológica (DT), observada além dos limites das categorias do gênero próximo e da diferença específica. $O$ trabalho conclui que é importante o reconhecimento do enunciado definitório em relação a todo um entorno de significação das linguagens cientificas envolvidas, evidenciando que a definição é um objeto textual multidimensional, dotado de características que o fazem exceder aqueles limites mais usuais ou tradicionais de um objeto lógico-categorial. Além disso, o trabalho demonstra que não é funcional, no seu enfoque, uma separação a priori e estrita entre conceitos e significados.

\section{ABSTRACT}

This paper deals with the apprehension conditions of the nature and functioning of the terminological definition (TD) from a perspective transcending the genus proximum and differentia specifica categories. Its conclusion stresses the importance of recognizing the definitory enunciation in relation to the meaning environment of the scientific languages involved. Definitions thus emerge as multidimensional textual objects that surpass the most usual or traditional limits of a categorial logical object. The study further demonstrates that a strict a priori break between concepts and meanings does not constitute a functional approach to the scientific terminological definition.

\section{PALAVRAS-CHAVE}

definição terminológica, termos técnico-cientificos, terminologia, estudo da definição

\section{KEY-WORDS}

terminological definition, scientific terms, terminology, studies of definition 


\section{Introdução}

O enunciado que define uma noção, processo ou objeto é um elemento-chave na constituição e na veiculação do conhecimento especializado, tecnológico ou científico. Afinal, expressa um segmento de relações de significação de uma determinada área do saber.

Para compreender a importância do seu papel, basta dizer que muito do que já se escreveu e do que ainda se tem escrito, por exemplo, em Química, depende de definições como as de átomo ou de ácido. Além disso, definições, ao constituírem textos particularizados, mostram e identificam facetas de compreensão de fenômenos no seio de uma determinada ciência. Isso se passa em diferentes ciências, inclusive na Lingüística: ao observarmos, por exemplo, diferentes definições que recebe um termo como língua, vemos variadas perspectivas de compreensão para esse tópico no âmbito dos estudos sobre a linguagem.

Entre diferentes tipos de definição, a definição terminológica (doravante DT) se particulariza por ser o enunciado-texto que dá conta de significados de termos ou de expressões de uma técnica, tecnologia ou ciência. Nesse caso, grosso modo, definir equivale a expressar um determinado saber, uma porção de conhecimento especializado. Esse enunciado envolve, portanto, uma representação conceitual particular, vinculada a um saber técnico, científico ou tecnológico.

Há distintas classificações de enunciados definitórios, oriundas tanto de diferentes objetos sob exame quanto de diferentes perspectivas e propósitos de estudo. Além das pesquisas mais atuais da Lingüística Cognitiva sobre modelos definitórios de itens de um léxico mental ou sobre estruturas conceituais (AITCHINSON 1994; PUSTEJOVSKI, 1995; WIERZBICKA, 1996; KLEIBER,1997; JACKENDOFF, 1997, entre outros), há toda uma tradição precedente de estudos sobre a definição que privilegiam enunciados verbalizados, principalmente os escritos. A partir desses estudos, os enunciados que, de modos variados, cumprem o papel de definir têm sido classificados como definições terminológicas ${ }^{1}$, lexicográficas, lógicas, explicativas ou enciclo- 
pédicas, entre outros tipos e subcategorizações, e geralmente têm sido apreciados em função da presença delimitadora, no próprio enunciado, de duas categorias basilares: o gênero próximo e a diferença específica.

Gênero próximo é a porção da definição que expressa a categoria ou classe geral a que pertence o ente definido. A diferença específica é a indicação da(s) particularidade(s) que distingue(m) o ente definido em relação a outros de uma mesma classe. Por exemplo, fosse uma definição de cadeira formulada como "peça do mobiliário que serve para sentar", o segmento "peça do mobiliário" corresponderia ao gênero próximo, enquanto que "serve para sentar" vale como diferença específica.

Para que haja uma boa formulação de uma definição, é usual reconhecer como importante (e esperar) que tanto o gênero quanto a diferença dêem conta, juntos, de uma delimitação, tal que a definição possa ser aplicada a um referente particularizado ${ }^{2}$. Assim, o definir é um de-finitio (REY, 1990, p.13), a colocação de uma limitação. Isso é o que não ocorre no exemplo antes citado da definição de cadeira, visto que nos limites colocados pelo enunciado "caberiam" também outros objetos, tais como poltrona, sofá, banco, pufe, etc. Melhor dizendo, a definição formulada tornou-se, especialmente na parte da diferença especifica, ampla demais para referir apenas uma classe bem particularizada de objetos.

Essas categorias, que representam um parâmetro de julgamento de qualidade e também um referencial para o estudo da definição desde os enfoques mais clássicos de Filosofia, Retórica e Lógica ${ }^{3}$, têm sido tomadas como principais pontos de reflexão e apreciação sobre a sua formulação. Ao longo do tempo, o gênero e a diferença vêm sendo utilizados e também "reinterpretados" ou "reciclados" de distintas maneiras em função de objetivos e de enfoques variados sobre a definição.

Os estudos clássicos, especialmente os de Lógica e de Gramáti$\mathrm{ca}^{4}$, como sabemos, influenciaram o desenvolvimento dos estudos lingüísticos, ajudando a imprimir-lhes feições que hoje identificam 
correntes de pensamento. Essa mesma influência também desencadeou uma tradição do estudo lingüístico da definição, procedido geralmente em função de verificar sua "correção" lógica ou de observar suas condições de verdade.

Nesse percurso, com o desenvolvimento da Terminologia de viés lingüístico $^{5}$, vemos também a perenidade do enfoque da definição de termos técnico-científicos pela observação das formulações do gênero e da diferença específica. Isso evidencia, por si só, uma herança lógico-filosófica, a mesma que atingiu os estudos lingüísticos em geral de diferentes modos e intensidades. Como veremos mais adiante, a apreensão lingüísticoterminológica da DT não se esgota por essas categorias, mas elas permanecem como um parâmetro crítico útil, desde que se considere também outras condições que perpassam esse tipo de enunciado.

A propósito de um interesse específico e ao mesmo tempo multifacetado sobre o tema "a definição", vale mencionar que a obra Essays on definition (SAGER, 2000) oferece a qualquer pesquisador, seja ou não lingüista ou estudioso de Terminologia, um panorama histórico do seu tratamento sob diferentes perspectivas. Esse trabalho inclui uma revisão e a reprodução de textos basilares sobre o tema: o pensamento de Platão, Aristóteles, Leibniz, Kant, entre outros, chegando até Heinrich Rickert e sua Teoria das Definições de 1888. Além de valiosa revisão histórica, abriga também o pensamento e a visão atuais de Rey (2000).

\section{A definição dicionarística}

A definição de dicionário pode ser vista como um protótipo ideal de definição, fornecendo um exemplo "modelar" para o seu estudo, especialmente para a DT. É comum encontrarmos considerações sobre a constituição da definição que partem da crítica sobre sua apresentação em dicionários de diferentes tipos. Veja-se, por exemplo, algumas interfaces e sobreposições entre definição enciclopédica, lexicográfica e terminológica em Finatto (1998). 
Examinando-se diferentes definições de dicionários especializados, é possível perceber um ponto comum fundamental: o enunciado definitório, na sua dimensão mais geral, caracteriza-se por realizar uma delimitação, mas, ao mesmo tempo, tende a ultrapassá-la. Nesse processo, o modo como a delimitação, acontece sofrerá variações em função das especificidades das diferentes áreas de conhecimento e também em função de outros fatores. Observemos, a seguir, como exemplos disso, um dicionário de Ciência Política e outro de Economia definindo o termo OLIGARQUIA. Depois, temos também como exemplo de variabilidade um dicionário de Física e um de Química que formulam distintas definições para o termo EFLORESCÊNCIA:

Dicionário de Economia

\section{Oligarquia}

Regime politico ou forma de dominação, de qualquer tipo, no qual o poder está nas mãos de um grupo pequeno de pessoas que dele se apossaram, sendo exercido apenas por elementos desse grupo. Do ponto de vista politico puramente formal, distinguese da democracia e da monarquia.

\section{Dicionário de Análise Política}

\section{Oligarquia}

Sistema de governo baseado no poder de um pequeno grupo de elite, não representativo e voltado para interesses próprios. Devido a seu sentido, normativo, o termo é em geral evitado na análise política em favor de outras classificações de conceitos usados na análise da elite. ARISTROCRACIA; ELITE; LEI FÉRRE A DE OLIGARQULA

\section{Dicionário Breve de Química}

\section{Eflorescência}

Um processo pelo qual um composto hidratado cristalino perde água formando um depósito em pó de cristais.

\section{Dicionário de Física Ilustrado}

\section{Eflorescência}

Fís.Quím. Formação dum sal anidro a partir de um bidratado, ou de um bidrato com menor número de moléculas de água a partir de outro mais hidratado, quando a pressão parcial de vapor de água na atmosfera em que está o sal hidratado é menor que a pressão de vapor deste sal. Os cristais do sal recobrem-se com cristalitos do outro sal menos hidratado, assumindo um aspecto pulvurulento. O fenômeno é aparentado com a deliqüescência. 
Nesses dois casos, com definições diferentes para OLIGARQUIA e EFLORESCÊNCIA, vemos apresentações definitórias que variam por diferentes motivos. Há um contraste de concepção significativo, por exemplo, sobre como se define e compreende OLIGARQUIA em Economia ou em Ciência Política, assim como há distinções na definição formulada para EFLORESCÊNCIA entre Química e Física. Chama a atenção o modo de construção do texto no Dicionário de Física, mais detalhado, contrastando com a brevidade da definição de Química ${ }^{6}$. De outro lado, vemos que o acréscimo de comentários, além de uma definição propriamente dita, é o elo comum entre as duas diferentes definições de OLIGARQUIA. Isto é, há, entre os diferentes enunciados, uma tendência para ir além da menção do gênero próximo e da diferença específica.

A partir da variabilidade desses dois exemplos, uma distinção entre as ciências e entre seus textos definitórios parece algo natural. Mas, algumas vezes, com o objetivo de buscar padrões lógicos estritos e uma homogeneidade estanque para a apresentação da definição, esquecemos que as diferenças e as heterogeneidades são inerentes à Linguagem. Isso, conseqüentemente, condicionaria ou espelharia padrões lógicos, subjacentes ou expressos, peculiares para as diferentes áreas do conhecimento.

Como a definição é um texto importante, é natural que a busquemos formular sob a forma de um enunciado claro e objetivo. Entretanto, um excesso de normatividade lógica, tanto tomado como medida de análise, quanto cobrado da sua apresentação, pode gerar alguns problemas quando se lida com definições concretas, reais. Portanto, adotar ou requerer um padrão de formulação uniforme, absoluto ou invariável, que possa valer para qualquer situação, ou privilegiar apenas uma forma lógica seria uma medida pouco inteligente na medida em que nos distancia da realidade da linguagem em geral e também de uma determinada linguagem técnica ou científica em uso. Afinal, a variação é um traço constitutivo da linguagem in vivo, seja ela especializada ou não. 


\subsection{Outras perspectivas sobre a definição}

Fora dos dicionários, em textos científicos e técnicos, em artigos de periódicos ou em livros, a definição para um termo aparece formulada de um modo "original" e costuma ter uma apresentação diferente da dicionarística. Essa definição "real" é geralmente um enunciado entrecortado por comentários, explicações, retomadas e exemplificações. Quando se discute o papel da definição e seus modos de formulação no âmbito dos estudos lingüísticos de Terminologia, principalmente quando o foco principal de interesse passa a ser o texto científico ${ }^{7}$, tais particularidades, variabilidades de formulação e "vicissitudes" deveriam poder ser incorporadas ao seu estudo sistemático, e não apenas desprezadas.

A definição tomada de dicionários é um objeto importante, representa um determinado padrão de enunciado definitório, mas é algo realmente cristalizado por conta de uma tradição de texto. Por isso, é preciso também considerar a realização desse tipo de enunciado em textos além de repertórios em geral e não simplesmente transpor um tipo de apresentação "ideal" para diferentes situações de texto e de comunicação.

Numa outra situação, à medida que a Terminologia, na perspectiva dos enfoques lingüísticos, se aproxima do texto e do objeto eminentemente textual que se tornou a definição de termos técnico-científicos, vemos um movimento de independência e de relativização da tradição lógico-gramatical. Nesse sentido, a trajetória atual dos enfoques da definição em Terminologia pode tender também para a identificação e para a consideração de elementos culturais e comunicativos, textuais e discursivos, presentes nos enunciados, o que, sem dúvida, é um passo muito importante rumo a uma visão mais integrada da comunicação, tanto entre especialistas e seus pares quanto entre especialistas e leigos. Para conhecer novas metodologias de observação da DT a partir corpora textuais científicos, veja, por exemplo, Pearson (1998 e 1999) ou Temmermam (2000). 


\section{Normas para a elaboração de definições}

Embora seja hoje contestada a imposição de padrões absolutamente rígidos para a formulação do enunciado definitório, as normatizações a respeito da DT permanecem como diretrizes úteis para a organização do texto que deve definir algo de modo que possa ser compreendido. A norma ISO 704 de 1987, por exemplo, estabeleceu algumas orientações básicas para a elaboração de definições que figuram em dicionários ou repertórios técnico-científicos.

Em linhas gerais, as recomendações das normas ISO dizem respeito à objetividade de formulação do enunciado e procuram garantir um bom fluxo de informação. São admitidas e comentadas, nesses documentos normativos, definições por intensão e definições por extensão. A definição intensional é a definição clássica com indicação do gênero próximo e da diferença específica. Intensão e extensão são categorias oriundas da Lógica, de onde provém, como já referimos, forte influência sobre o assunto "definição". A definição por extensão, por sua vez, consiste da enumeração dos entes a que se aplica uma designação. É um exemplo desse tipo a definição a seguir:

\section{Planetas do sistema solar}

Mercúrio, Vênus, Terra, Marte, Júpiter, Saturno, Urano, Netuno.

Outra recomendação dessa norma ISO estabelece que o seu redator se atenha à apresentação das características mais essenciais do objeto que define. A indicação é de que a definição deva seguir um padrão direto. Comentários, intercalações e explicações acessórias devem vir em segundo plano, uma vez que o enunciado deverá informar em primeiro lugar o que é o termo ou expressão em foco. Em segundo lugar, então, devem vir indicações de composição, causa, origem, etc.

Ao ignorar essas orientações normativas, um enunciado como o a seguir, pretendendo definir água, seria considerado pouco satisfatório para ser utilizado em um glossário de termos de Física: 


\section{Água}

Desde os tempos antigos, a água é um valor essencial para o homem, além disso é um líquido cujo ponto de congelamento é $0^{\circ} \mathrm{C}$ e que tem ponto de ebulição em $100^{\circ} \mathrm{C}$.

São aspectos fundamentais para a qualidade do enunciado definitório, a adequação à situação comunicativa, objetividade e consistência como texto. Por isso, conforme as regulamentações ISO, definições incompletas, tautológicas, circulares ou aquelas que "começam pelo fim" devem ser evitadas. Do mesmo modo, não são recomendadas as definições que iniciem por expressões de fuga, tais como "expressão que geralmente denota", por uma negação ou por palavra gramatical diferente do termo que se define. Seria um equívoco, por exemplo, formular uma definição no plural para um termo no singular.

\section{Uma nova lógica para a definição}

Fora do âmbito da normatização, como o viés lógico implicado na apreciação da definição é algo freqüente, acreditamos que vale a pena trazer aqui uma amostra de concepção em que isso se verifica exemplarmente. Entretanto, nos parece necessária uma visão mais moderna, visto que o cartesianismo lógico e a lógica clássica são apenas uma etapa da tradição desses estudos.

Os estudos de Lógica atual, vale mencionar, permanecem reconhecendo as categorias do gênero e da diferença como as condições mínimas e absolutamente necessárias para a formulação de uma definição "logicamente correta" e "minimamente inteligível". Um bom exemplo dessa conservação pode ser visto na apresentação de problemas da definição feita no trabalho intitulado Introdução à Lógica (COPI, 1978).

Copi (op.cit., p.105-119) também reconhece o gênero e a diferença como os melhores (grifo nosso) métodos de definir. Afirma que, de seu ponto de vista, a definição em geral é um enunciado que tem cinco propósitos: 1) aumentar o vocabulário; 2) eliminar ambigüidades; 3) aclarar significados; 4) explicar teoricamente; e, 5) influenciar 
atitudes. A partir dessas diferentes finalidades da definição, pelo que vemos do seu trabalho, a DT, que não é examinada em particular, poderia ser vista de dois modos.

Primeiro, pode ser vista como uma definição de tipo estipulativo, vinculando-se à criação de termos novos que denominam novas realidades ou "inventos". Essa definição não seguiria parâmetros fixos, pois o autor/criador terá a plena liberdade de estabelecê-la como melhor decidir. O redator da definição, neste caso, é o cientista que "inventa coisas" e as novas palavras para denominá-las.

Em segundo lugar, a DT, por suas características, pode ser vista como um tipo de definição que o autor qualifica como definição teórica. Essa definição, segundo tal perspectiva lógica, serve para "explicar teoricamente", e, para Copi (op.cit.), é aquela que tenta formular uma caracterização "teoricamente adequada" dos objetos a que se aplica. Como assinala o autor, propor uma definição desse tipo equivale a propor a aceitação de uma teoria. Um exemplo ilustrativo trazido por ele envolve a definição de termos de Química:

"Outro exemplo de enunciado que tem a finalidade de servir a esse propósito é a definição de 'ácido', uma substância que contém bidrogênio como um radical positivo. Tudo o que é corretamente chamado ácido, no uso fluente, é denotado pelo termo tal como o químico o define, mas não se pretende que o princípio usado pelo químico para distinguir os ácidos das outras substâncias seja aplicado pelas donas de casa ou pelos que trabalham na laminação de metais quando empregam o mesmo termo. A definição do químico tem o intuito de incluir na significação da palavra aquela propriedade que é mais útil, no contexto de sua teoria (grifo nosso), para compreender e prever o comportamento daquelas substâncias que a palavra denota. Quando o cientista elabora tais definições, seu propósito é teórico." (COPI, op.cit., p.109)

A partir dessa citação, vemos que a corrente lógica a que se filia o autor consegue ir um pouco à frente da idéia basilar e simples de um "padrão lógico de correção", colocando a definição teórica, que se aproxima muito da nossa DT, como algo que é naturalmente marca- 
do pela interferência de um sujeito e pela discussão ou controvérsia. É, assim, condicionada pelo que chamamos de entorno de significaşão (FINATTO, 2001a, p.146ss.) ou por um determinado"ambiente teórico", elementos que poderiam ser adicionados ao "significado de base" da "palavra". E, como há tal condicionamento, é fácil concluir que seria pouco produtivo "exigir" do enunciado uma formulação fixa sempre e apenas em termos do gênero próximo e da diferença específica.

\section{Tradição lexicográfica e contribuições de teorias semânticas}

Muitas das considerações que encontramos sobre a DT são transposições do que já se observou a partir da definição que aparece em dicionários comuns de língua. Assim, é importante saber que há também uma tradição lexicográfica bastante presente no seu estudo, quer em Terminologia quer em outras áreas.

Recorrendo ao exemplo da definição tipicamente lexicográfica de cadeira, formulada como "um móvel com assento, com encosto $e$ que serve para sentar" veremos, numa metodologia de análise derivada da semântica estrutural, que as categorias do gênero próximo SER UM MÓVEL e do gênero especifico TER ASSENTO, TER ENCOSTO e SERVIR PARA SENTAR lhe conferem uma apresentação tida como "modelar". Não obstante, a definição usual de uma palavra, vista em um dicionário comum, até pode apresentar outros elementos complementares, como informações etimológicas, comentários estilísticos e gramaticais ou até conter uma explicação detalhada sobre a diferença entre poltronas e cadeiras no século XVIII. Ainda assim, se reconhece que as duas categorias fundamentais do gênero e da diferença não poderão estar ausentes do enunciado, sob pena de impedirmos o entendimento da definição, sobretudo se a palavra que encabeça o verbete do dicionário for estranha para o consulente.

Em determinada fase da semântica estrutural, quando se enfocou a construção do significado de uma palavra com o recurso de categorias para acomodar as "virtualidades de sentido", tal como vimos nos 
trabalhos de Pottier (1978) e, principalmente, em Greimas (1968 e 1973), permaneceram vestígios das mesmas categorias aristotélicas do gênero e da diferença. A sua apropriação, entretanto, deu-se por um viés que, embora abandone uma compartimentalização estanque, reconhece um "papel preponderante que é preciso atribuir à construção lógica na descrição semântica” (GREIMAS, 1973, p.91).

$\mathrm{Na}$ história recente dos estudos lingüísticos, o gênero e a diferença permanecem como elementos importantes. Mas, de um outro modo, passam a ser vistos como um conjunto de traços binários, tal como se costumava apresentar numa clássica definição da palavra menina pelo conjunto dos traços [ + ser humano, - adulto, + sexo feminino]. Assim, a definição de palavras, quer seja colhida de dicionários, quer seja de outra fonte textual, passou a ser observada em função da presença ou ausência de determinados traços sêmicos que, diferente da categorização via gênero e diferença, são questionados em seus modos de existência e em relação a um universo de discurso.

Um outro exemplo da manutenção e do modo de reconhecimento das categorias do gênero próximo e da diferença específica por parte de lingüistas pôde ser visto no trabalho de J. Rey-Debove (1971, p.227). Segundo explicava a autora, a definição terminológica é uma definição de especialista, que remete a um corpo de conhecimentos, notadamente através da escolha do gênero próximo. Mas, no caso de uma definição para "o grande público", a definição terminológica reflete um nível médio de conhecimento e será constituída por um "incluente médio", que corresponde a uma categoria referencial diferente do gênero próximo. Isto é, a categoria do gênero próximo, em algumas situações, poderá ser transformada em algo que poderíamos chamar de gênero médio. Essa, sem dúvida, é uma perspectiva interessante e ainda hoje aproveitável porque não ignora a condição referencial da definição, naturalmente aberta e transformável pelo sujeito enunciador em função das necessidades e objetivos da interlocução estabelecida via texto definitório. 


\section{Novos rumos para compreender a DT}

Entre os estudos lingüísticos e os estudos de Terminologia de perspectiva lingüística, a concepção de "uma boa definição" ou de uma definição minimamente necessária e suficiente permanece alicerçada na utilização, quer na perspectiva lógica, quer na perspectiva lingüística, das categorias do gênero próximo e diferença específica. Mesmo nas propostas iniciais de uma semântica derivada da vertente gerativo-transformacional, reaparecem essas categorias, "reeditadas" sob a forma de traços que migram de uma estrutura de superfície para a estrutura profunda e vice-versa.

Entretanto, como se pode antever, a compreensão da definição como um sistema categorial, de tipo binário ou sustentado por um sistema de traços associado aos valores + , - e $\varnothing$, será abalada a partir do momento em que comecemos a necessitar representar a definição de palavras de significação "virtual" ou mutável, palavras que, no seio das ciências ou tecnologias, correspondam a objetos ou conceitos de natureza híbrida, que possam ou precisem ser definidos de maneiras difusas ou pouco ortodoxas, para as quais + , - e $\varnothing$ sejam insuficientes.

De outro lado, observar apenas a categorização já é também insuficiente quando, tomada como uma taxionomia, questionamos onde está ou onde termina o gênero e onde começa a diferença em uma definição. Algumas vezes, a diferença parece fazer parte do gênero; noutras o gênero parece ser vinculado a um valor de significação bastante vago, que, enfim, pode dizer ou significar muito pouco, tais como os usuais "começos de definição" por elemento, condição, propriedade, ente, etc. O mesmo acontecerá quando os valores categoriais dos traços sim, não e žero forem insuficientes ou, principalmente, irrelevantes.

Para além dos limites do gênero próximo e da diferença específica, encontramos, como um parâmetro "moderno" e mais usual de descrição e análise lingüística, o modelo de sua representação proposicional. Nesse modelo utiliza-se, via de regra, o procedimento do 
cálculo de predicados para a apreciação do enunciado definitório. Nessa perspectiva, que tem sido aproveitada pela Terminologia lingüística, o conceito ou significado expresso pela definição de uma palavra ou de um conceito é depreendido pela relação básica argumento-predicado. Assim, o enunciado passa a ser "traduzido" ou reescrito com o auxilio das proposições, que, presumidamente, estão explícitas ou subjazem ao enunciado concreto. São indicadas, então, as categorizações ou predicações referidas ao termo ou palavra que está sendo definido. Assim, por exemplo, se tivéssemos "o DNA é uma proteína", a definição de DNA seria vista como uma apresentação lingüística para a relação \{DNA (SER) PROTEÍNA\}.

Mas, para o caso da definição ser " $D N A$ - uma proteína ácida, presente nos genes dos seres vivos", a representação proposicional seria um tanto mais complexa:

\{DNA (SER) \{PROTEÍNA (SER) ÁCIDA (ESTAR EM) \{GENES (PERTENCER A) SERES VIVOS $\}$ \} $\}$

Esse tipo de representação do enunciado permite que sejam colocados em relevo os argumentos DNA, PROTEÍNA, GENES, SERES VIVOS, o qualificativo ÁCIDO e os predicados SER, ESTAR EM e PERTENCER A. A utilidade desse tipo de representação, em tese, reside no fato de se poder empreender um "mapeamento" de argumentos e, principalmente, de predicados mais recorrentes em textos definitórios de determinada ciência ou especialidade.

\subsection{Outras contribuições}

A idéia de transformação de uma definição em um conjunto proposicional é, evidentemente, mais ampla do que a categorização mais estanque do gênero próximo e diferença específica. Todavia, também não oferece um padrão suficiente ao analista do enunciado, principalmente quando tivermos definições com estruturas sintáticas mais complexas. 
Uma boa ilustração de problemas da representação proposicional seria:

\section{Gaxeta}

Peça mecânica circular, de borracha escura. Tipo de engrenagem inventada pelo engenheiro John Helmuth, em 1890, para ser utilizada como instrumento de diminuição de impacto entre dois discos metálicos.

$\mathrm{Na}$ descrição dessa definição fictícia, mesmo que fossem usadas somente as categorias do gênero próximo e diferença especifica, teríamos, entre outras, a dúvida se a categoria do gênero é composta somente pela palavra peça ou pelo sintagma peça mecânica. Numa análise em moldes proposicionais, com cálculo de predicados, haveria a necessidade, considerando apenas o caso do verbo SER, de diferentes subcategorizações:

(GAXETA SER inclusão $_{\text {(PEÇA SER }}$ qualificativo MECÂNICA, CIRCULAR )) (GAXETA SER $_{\text {feita de }}\left(\right.$ BORRACHA SER ${ }_{\text {qualificativo }}$ ESCURA )) ou (GAXETA SER $_{\text {tipo de }}($ ENGRENAGEM))

Extrapolando as dificuldades de um método ou de outro, há outras opções que poderiam ser mais promissoras para o estudo da definição em Terminologia. Entre diferentes possibilidades e naturais dificuldades de representação de enunciados definitórios por meio da relação argumento/predicado, destacou-se a inovadora visão de G. Lakoff (1987). Esse autor considerou, para a representação do semantismo de um enunciado definitório, a existência de categorias relacionais ou relações conceituais compostas por subcategorias mais centrais e menos centrais, mais ou menos prototípicas.

Isto é, as categorias indicadas em um enunciado como, por exemplo, "a mulher é um ser humano" e representadas por [MULHER, (SER) SER HUMANO] não serão, segundo o autor, homogêneas ou simplesmente hierárquicas, mas, antes disso, serão mais ou menos 
prototípicas, típicas ou simplesmente referenciais, principal e fundamentalmente porque são culturalmente modeladas. Afinal, em alguns lugares ou sociedades, em função do tipo de modelo cognitivo adotado, não se definiria mulher como ser humano, mas sim como propriedade do pai, marido ou tutor.

Essa concepção sobre categorias lógicas ${ }^{8}$ pode indicar um avanço importante para a Terminologia porque, no que se refere às definições terminológicas, sabemos que, em função de vários fatores, mais ou menos aproximados às condições do caso acima citado, é possível encontrar diferentes definições para um mesmo termo, tanto nas técnicas, quanto nas ciências, e, não raro, diferentes e multiplicadas definições de um termo em apenas uma mesma área ou especialidade.

Esse tipo de fenômeno, contrário ao ideal de uma comunicação profissional absolutamente precisa e totalmente unívoca, tem sido historicamente atribuído principalmente às áreas humanas do conhecimento. O trabalho de Lakoff (op. cit.) e sua idéia de uma "semântica culturalmente modelada", em seu grande mérito, oferece-nos uma maior opção de categorias, tidas como naturalmente difusas, aplicáveis à análise de DT's. Isso é muito importante porque, afinal, resgata a idéia historicamente excluída de que alguém ou algo interfira sobre a categorização observada pelo analista, mostrando que o texto definitório, enfim, não acontece por si.

Seguindo essa tendência de novas compreensões para o objeto definitório, a tese de doutoramento de R. Temmermann (1998), intitulada Terminology Beyond Standardisation: Language and Categorisation in the Life Sciences, e também seu recente livro (TEMMERMAN, 2000), com a proposição de uma Terminologia sócio-cognitiva, são exemplos de trabalhos que desenvolvem a perspectiva lakoffiana dos Modelos Cognitivos Idealizados. Enfatizando a presença de recursos metafóricos na linguagem científica, o pensamento da autora destaca-se no atual panorama dos estudos terminológicos que seguem um ponto de vista lingüístico, pois potencializa o avanço de um enfoque da definição que poderá ser realmente mais lingüístico do que conceitual. 
Antes dessas iniciativas, uma outra perspectiva dos estudos lingüísticos já vinha sendo aproveitada para o estudo das linguagens e terminologias técnico-científicas, trata-se do trabalho de Pustejovsky (1995), The Generative Lexicon. Nele, o autor postula que o significado de uma unidade léxica seja estruturado, na sua gramática, em quatro níveis interligados, sujeitos a transformações distintas. Um desses níveis é a estrutura qualia, na qual estão contidas as informações semânticas básicas de uma palavra, tais como CONSTITUIÇÃO, FORMA, PROPÓSITO, FUNÇÃO e características de AGENTIVIDADE. Essas informações interagem com as informações do nível sintático da gramática e geram o quadro das restrições semânticas necessárias à compreensão da palavra em seus usos na linguagem.

Essa idéia possibilita uma representação do enunciado da definição como uma estrutura qualia, que é um conjunto categorial modelado por condições sintáticas. Observe-se, nesse enfoque, um relativo apagamento de outras condições, principalmente daquelas que estejam fora da sintaxe, como os mecanismos de enunciação ou determinadas peculiaridades definitórias.

\section{Da lógica ao cognitivismo psicológico}

O enfoque da DT na Terminologia lingüística tem sido marcado pela apreensão lógico-categorial do enunciado definitório. A falta de uma compreensão realmente lingüística da DT e uma compartimentalização estanque entre o que lhe seria interno ou externo perfazem os problemas mais recorrentes para análises e metodologias descritivas delineadas no seio das teorias de viés lingüístico.

$\mathrm{Na}$ perspectiva lógico-filosófica da definição, ainda que a redução lógico-proposicional seja operada por categorias prototípicas e culturais, com eventual destaque para as categorias estabelecidas pela metaforização, e mesmo que se prefira continuar a redução do enunciado definitório às "clássicas" categorias do gênero e diferença, é importante refletir um pouco mais cuidadosamente sobre o elemento comum a esse tipo de aproximação aos fenômenos da linguagem: a 
categorização lógica do enunciado. Sobre isso, o reconhecimento de Van Dijk é um alerta já antigo, mas sempre necessário recuperar no escopo das análises lógico-formais: "a estrutura das orações da língua natural é tão complexa, que sequer a lógica standard mais sofisticada a reconstrói adequadamente" (VAN DIJK: 1984, p.75).

Uma aproximação entre conceitos e significados, no âmbito da definição, tem sido questionada, de um modo naturalmente distinto, também pela chamada Psicologia Cognitiva. Nessa corrente da Psicologia, muitos autores já destacaram que a linguagem não proporciona uma janela direta para os conceitos humanos, além de sublinharem que conceitos seguem sendo uma forma consideravelmente diferente de seus "primos" proposicionais. Isto é, e aqui vale um grifo, nem mesmo os psicólogos cognitivistas admitem a equivalência entre um conjunto proposicional de fundo lógico e um conceito. Mas, apesar disso, a equivalência tem sido comum em Terminologia quando se analisam definições.

Nesse caminho, um conjunto proposicional tende a ser um objeto manipulado pelo terminólogo-lingüista que, a partir das proposições, deixa de observar significados para ver apenas conceitos! Assim, acreditamos que é válido estender nosso olhar também sobre o modo como a Psicologia concebe e descreve conceitos, com vistas a melhor nos posicionarmos, como lingüistas, sobre os significados que, teoricamente, deveriam ser nosso foco principal de atenção.

No escopo da Psicologia e da Ciência Cognitiva, cada vez mais se questiona se conceitos seriam ou não independentes de contexto ou situação e se seriam realmente universais, enquanto que os significados sempre são qualificados como dependentes e compreendidos como não universais, ainda que os modelos lingüístico-gerativos postulem uma semântica de valores de significação universais. E, nesse âmbito psicológico, de um modo que nos parece bastante interessante, conceitos passaram a ser percebidos em frames que interferem sobre os significados, oferecendo-lhes domínios ou escopos de referência.

Há uma distinção bastante problemática e controversa entre con- 
ceitos, significados, categorias e protótipos também na Psicologia e na Ciência Cognitiva, que inspiraram uma Semântica e Lingüística Cognitivas, destacando-se um reconhecimento recorrente de limites para a categorização. Por isso, acreditamos que a Terminologia de orientação lingüística, ao incursionar pelas vertentes cognitivistas dos estudos da linguagem, pode desenvolver sua própria perspectiva e abster-se dessa diferenciação quando lida com enunciados definitórios. Vale assumir como inerente a interface linguagem/conhecimento sem querer ingenuamente "resolvê-la", tratando de privilegiar nos enunciados, de sua parte, os significados a eles vinculados. Isso já é algo muito importante e que nos afastaria de algumas contradições.

\section{A definição antes de tudo é um texto}

Os diferentes enfoques da DT encontrados na literatura lingüística e terminológica ainda não alcançaram o patamar de considerá-la como um texto de múltiplas dimensões. Tendem a transformá-la num objeto representacional monofacetado com o auxílio de descrições excessivamente formalizantes, que geralmente dela excluem aqueles elementos tidos como assistemáticos ou idiossincráticos. Em geral, na análise dos enunciados, são descartados alguns elementos de informação importantes e funcionais, apenas em função de serem $a$ priori supérfluos, heterogêneos ou acessórios.

Ainda que já se tenha reconhecido, além da redução lógica, a importância de uma descrição da dimensão de discurso ou de contexto pragmático, tal como já indicava o trabalho de Van Dijk (1984), como já havia pensado nos anos oitenta L. Hoffmann (vide HOFFMANN, 1998) ou como, mais recentemente, fez Beaugrande (1996), para o reconhecimento de textos especializados, é preciso voltar a atenção para o texto definitório em si mesmo. Não se deve apenas acatar um modelo prévio de observação da DT, tampouco um modelo de formulação, mas é preciso inscrevê-lo relacionalmente em algo mais amplo, simultaneamente construído pelo indivíduo-autor e pela coletividade que ele representa. Importa recuperar, enfim, a autoria, am- 
biência e, fundamentalmente, a natureza lingüística da definição de termos técnico-científicos.

E, ainda que se prefira ou necessite estabelecer fronteiras entre conceitos e significados, quando se tratar da DT, é imprescindível ter em conta, tal como magistralmente percebeu Cassirer, que "os conceitos fundamentais de uma dada ciência, meios pelos quais apresenta suas questões e soluções, não aparecem mais como cópias passivas de um ser dado, senão como símbolos intelectuais criados por ela" (grifo nosso, CASSIRER: 1964, [trad. de 1971] p.14). O mesmo se aplica, segundo entendemos, aos significados das "palavras-termo", unidades lexicais de significação especializada, fixados, de diferentes modos e com diferentes graus de especificidade, pelos enunciados definitórios.

\subsection{Um caminho possível: a contribuição benvenistiana}

Conforme vemos, é bastante viável a contribuição das teorias enunciativas para os estudos mais recentes de Terminologia dedicados à definição, principalmente se forem conjugadas com uma apreciação crítica do que a Psicologia Cognitiva e a Filosofia da Linguagem já nos revelaram sobre a relação entre significados e conceitos. Especialmente promissores, na nossa opinião, são os fundamentos das teorias de semântica de enunciação, na teoria delineada na obra de Émile Benveniste $^{9}(1989$ e 1991). Ainda que relativamente "antigos", terão muito a render para a Terminologia.

Dizemos isso porque esse autor propôs um redimensionamento da noção de língua e linguagem a partir da crítica da exclusão saussuriana de um sujeito que interfere sobre língua, um sujeito que propriamente faz a linguagem. E, como é fácil reconhecer e deduzir de muitas das atuais dificuldades das descrições terminológicas, pouco se tem tratado do sujeito em Terminologia, de modo que a linguagem científica ou técnica tende a ser apresentada como algo associado à imagem de um saber sem autoria definida, como se fosse algo feito por si próprio, sem que nenhum sujeito a tivesse produzido ou nela se 
auto-representasse. Esse tipo de compreensão revela a persistência de um ideal absoluto de "neutralidade científica" vinculado principalmente aos textos científicos, à sua impessoalidade, nos seus mais diferentes tipos ou gêneros.

A contribuição enunciativa é adequada à Terminologia também e justamente pelo questionamento de Benveniste acerca da noção de arbitrariedade do signo lingüístico, uma vez que o emprego e a constituição metafórica de alguns termos científicos constituem uma realidade que não pode ser mais negada (sobre o recurso da metaforização na DT e em textos científicos, veja KOSTINA, 2000). Ao afirmar que "é necessário ultrapassar a noção saussuriana do signo como princípio único", Benveniste (1989, p. 67) aponta que a ultrapassagem se fará por meio da abertura de uma nova dimensão de significância, a do discurso, e também pela via da análise intra- e translingüística dos textos.

Há toda uma afinidade entre teorias de enunciação e Terminologia, uma convergência a ser explorada ${ }^{10}$, expandida e aproveitada: questões e impasses da investigação atual sobre as linguagens especializadas e principalmente sobre a definição de diferentes termos científicos e técnicos só têm a lucrar com uma aproximação com as idéias de Benveniste, com seu modo de analisar e de refletir sobre a linguagem. A sua idéia de apropriação da língua por uma classe ou segmento social é apenas um exemplo do seu potencial de contribuição.

Recebido em abril de 2002. Versão revisada aceita em agosto de 2002.

\section{Referências bibliográficas}

AITCHINSON, Jean. Words in the mind. An introduction to the mental lexicon. 2.ed. Oxford/Cambridge, Blackwell, 1994. BEAUGRANDE, Robert de. LSP and terminology in a new science 
of text and discourse. In: GALINSKY, Christian; SCHMITZ, Klaus-Dirk. TKE' 96 Terminology and knowledge engineering. Frankfurt/M: Indeks Verlag, 1996. p.12-26.

BENVENISTE, Émile. (1989) Problemas de Lingüistica Geral II. Campinas: Pontes. 1989.

BENVENISTE, Émile. (1991) Problemas de Lingüística Geral I. Trad. Maria da Glória Novak e Maria Luiz Neri. 3.ed. Campinas: Pontes, 1991. 387p.

COPI, Irving Marmer. Introdução à Lógica. Tradução de Álvaro Cabral. 2.ed. São Paulo: Mestre Jou, 1978. 488p.

FINATTO, M. J. B. (1998) Elementos lexicográficos e enciclopédicos na definição terminológica: questões de partida. Organon, Porto Alegre: UFRGS, vol.12, n.26, 1998.

FINATTO, M. J. B. (2001a) Definição terminológica: fundamentos teóricometodológicos para sua descrição e explicação. Porto Alegre: UFRGS, 2001 (a). 395p. Tese (Doutorado em Estudos da Linguagem). Instituto de Letras, Universidade Federal do Rio Grande do Sul, 2001.

FINATTO, M.J.B (2001b) A definição terminológica no dicionário TERMISUL: expressão lingüística de relações conceituais complexas. In: OLIVEIRA, Ana Maria P. de; ISQUERDO, Aparecida N. (orgs.) As Ciências do Léxico. $2^{\mathrm{a} e d . ~ C a m p o ~ G r a n d e, ~}$ MS:Ed. UFMS, 2001. 268p. p.211-224.

FINATTO, M.J.B (2001c) Terminologia e ciência cognitiva. IN: KRIEGER, M. da Graça.; MACIEL, Anna M.B.(orgs.) Temas de Terminologia. Porto Alegre/São Paulo: Ed.Universidade/UFRGS/ Humanitas/USP, 2001. p.141-149.

GREIMAS, A J. (1968) Du sens. Paris: Du seuil, 1968.

GREIMAS, A. J. (1973) Semântica estrutural. São Paulo: Cultrix, 1973. HAUSMANN, F.J. La définition est-elle utille? In: CHAURAND, Jacques; MAZIÈRE, Francine. (eds.) La Définition. Actes du Colloque la Définition. 18-19 Nov. 1988. Paris: Larousse, 1990. p.208-224. 
HOFFMANN, Lothar. Llengatges d'especialitat. Org. por Jenny Brumme. Barcelona: Universitat Pompeu Fabra, 1998.

JACKENDOFF, Ray. The Architecture of the Language Faculty. Cambridge/London, MIT Press, 1997.

ISO 704. International Standard. Principles and methods of terminology. Switzerland, 1987, 16 p.

KLEIBER, Georges. Sens, réference et existence: que faire de léxtralinguistique? Langages: Langue, praxis et production du sens. Paris, n.127, September 1997, p.9-37.

KOSTINA, Irina. Dinamicidad de los Conceptos Especializados em los Textos de Diferente Nivel de Especialización. Trabajo de Investigación. Bella Terra: Universidad Autónoma de Barcelona, 2000.

LAKOFF, George. Women, fire, and dangerous things. What categories reveal about the mind. Chicago: University of Chicago Press, 1987. PEARSON, Jeniffer. Terms in context. Amsterdam: John Benjamins, 1998.

PEARSON, Jeniffer. (1999) Comment accéder auxs éléments définitoires dans les textes spécialisés? Terminologies nouvelles. Québec: Rint (Réseau international de néologie et de terminologie). N.19, décembre 1998, juin, 1999. p.21-28.

POTTIER, B. Lingüistica geral: teoria e descrição. Rio de Janeiro: Presença, 1978.

PUSTEJOVSKY, James. The Generative Lexicon. Cambridge: The Mit Press, 1995. 298p.

REY, Alain. (1990) Polysémie du terme definition. In: CHAURAND, Jacques; MAZIÉRE, Francine. (orgs.) La Définition. Paris: Larousse, 1990. 304p. p.11-22.

REY, Alain. (2000) Defining definition. In: SAGER, Juan C. (org.) Essays on definition. Amsterdam/Philadelphia: John Benjamins, 2000. 256p. p.1-14.

REY-DEBOVE, J. Étude linguistique et sémiotique des dictionnaires français contemporains. La Haye: Mouton, 1971.

SAGER, Juan C. (org.) Essays on definition. Terminology and 
Lexicography Research and Practice. Amsterdam/Philadelphia: John Benjamins, 2000. 256p.

TEMMERMANN, Rita. (1998) Terminology Beyond Standardization: Language and Categorizations in the Life Sciences. Leuven: Catholic University, 1998. 307p.

TEMMERMANN, Rita. (2000) Towards New Ways of Terminology Description. The sociocognitive approach. Philadelphia: John Benjamins, 2000. 258p.

VAN DIJK, Teun A. Texto y contexto. Semântica e pragmática del discurso. 2.ed. Trad. de Juan Domingo Moyano, Madrid: Cátedra, 1984. $357 \mathrm{p}$.

WIERZBICKA, Anna. Semantics, primes and universals. NewYork: Oxford Universtiy Press, 1996.

*Texto elaborado com o aproveitamento de algumas seções de FINATTO (2001a), tese de doutorado em Teorias do Texto e do Discurso, PPG Letras/UFRGS, que trata, em maior amplitude e profundidade, do tema da definição terminológica sob a ótica dos estudos de Terminologia.

${ }^{1}$ Há quem questione a existência desse tipo definitório em especial e também de outros. Hausmann (1990, p.233), por exemplo, ao comprovar a vagueza das informações definicionais de dicionários em geral, salienta que informações situacionais, iconográficas e sintagmáticas seriam muito mais propriamente definitórias do que tais enunciados.

${ }^{2}$ Naturalmente estamos aqui no plano de uma exigência lógica, de um recorte, isso não significa que o enunciado definitório se aplique apenas a um objeto em especial totalmente particularizado. Isto é, uma definição suficientemente específica de cadeira se aplica a vários tipos de cadeira.

${ }^{3}$ Para um bom panorama desses estudos dedicados à definição, veja Sager (2000).

${ }^{4}$ Sobretudo pela via da distinção entre Lógica e Metafísica. 
${ }^{5}$ A Terminologia, como disciplina, nasceu bastante distanciada da Lingüística. Apenas numa segunda fase de seu desenvolvimento moderno, por volta de 1982, instaura-se, aos poucos, uma perspectiva lingüística dos fenômenos da linguagem técnico-científica. A perspectiva lingüística é oposta à versão "clássica", predominantemente vinculada à observação de conhecimentos, ontologias e distanciada da observação de "palavras". A vertente "clássica", ao privilegiar "termos", lida com conceitos, preferentemente padronizados, e tende a desprezar a observação de significados ou peculiaridades lingüísticas.

${ }^{6}$ Embora o nome do dicionário contenha "breve", apresenta algumas definições bem extensas.

${ }^{7}$ Incluindo seus diferentes tipos, tais como texto científico didático e também textos de popularização de temas de ciências.

${ }^{8}$ Para outros detalhes sobre a concepção categorial prototípica, veja Finatto (2001c).

9 Para maiores detalhes sobre essa discussão, veja, na obra de Benveniste acima citada, o texto $A$ semiologia da Lingua, capítulo 3. Um outro exemplo bastante interessante do potencial benvenistiano para a pesquisa em Terminologia é exame do recurso da metaforização e de outras propriedades da linguagem pelo enunciador cientista. Alguns escritos de Benveniste inclusive exploram o processo de criação de uma nova terminologia em textos científicos e a difusão/vulgarização de termos eruditos. No texto Novas formas de composição nominal, capítulo 12, na mesma obra, por exemplo, o autor examina a origem do termo micróbio e discute o modo de uso peculiar do cientista de formantes greco-latinos, um assunto recentemente explorado na Terminologia de perspectiva lingüística.

${ }^{10}$ Veja um exemplo de aproveitamento do referencial benvenistiano para a observação de definições de Química em contraste com definições de Ciência Política em Finatto (2001a). 